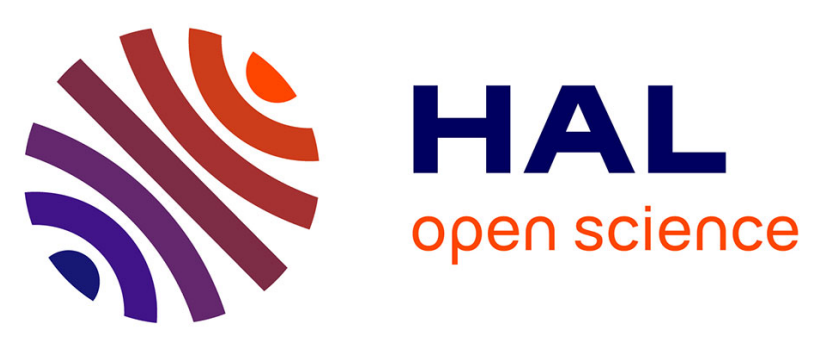

\title{
NON METHANE HYDROCARBONS CHEMISTRY IN THE ATMOSPHERE OF AN EQUATORIAL FOREST' A CASE OF INDIRECT PHOTOCHEMICAL PRODUCTION OF OH RADICALS
}

\author{
B. Bonsang, M. Kanakidou, G. Lambert
}

\section{To cite this version:}

B. Bonsang, M. Kanakidou, G. Lambert. NON METHANE HYDROCARBONS CHEMISTRY IN THE ATMOSPHERE OF AN EQUATORIAL FOREST' A CASE OF INDIRECT PHOTOCHEMICAL PRODUCTION OF OH RADICALS. Geophysical Research Letters, 1987, 14 (12), pp.1250-1253. 10.1029/g1014i012p01250 . hal-03545743

\author{
HAL Id: hal-03545743 \\ https://hal.science/hal-03545743
}

Submitted on 27 Jan 2022

HAL is a multi-disciplinary open access archive for the deposit and dissemination of scientific research documents, whether they are published or not. The documents may come from teaching and research institutions in France or abroad, or from public or private research centers.
L'archive ouverte pluridisciplinaire HAL, est destinée au dépôt et à la diffusion de documents scientifiques de niveau recherche, publiés ou non, émanant des établissements d'enseignement et de recherche français ou étrangers, des laboratoires publics ou privés. 
NON METHANE HYDROCARBONS CHEMISTRY IN THE ATMOSPHERE OF AN EQUATORIAL FOREST:

A CASE OF INDIRECT PHOTOCHEMICAL PRODUCTION OF OH RADICALS.

B. Bonsang, M. Kanakidou, and G. Lambert

Centre des Faibles Radioactivités, Laboratoire mixte CNRS/CEA Avenue de la Terrasse, 91190 Gif-sur-Yvette, France

Abstract. An experiment was conducted in the Guyana forest in March 1985 , during which $C_{2}-C_{6}$ non methane hydrocarbons (NMHC) were measured in the air, together with $\mathrm{CO}_{2}$ and its associated ${ }^{13} \mathrm{C}$ isotopic composition. Owing to the very high atmospheric stability, strong vertical concentration gradients were observed close to the soil surface. Simple assumptions allow showing that NMHC are mainly destroyed by $O H$ radicals whose concentration seems to be surprisingly high, around $1 \times 10^{7}$ radicals $\mathrm{cm}^{-3}$. An indirect photochemical production of these radicals is proposed.

On the other hand, the fluxes of the different NMHC emitted from the litter were found to be small, in the range of $10^{-7}$ to $10^{-6} \mathrm{~g}$ of carbon per hour and per $\mathrm{m}^{2}$.

\section{Introduction}

Although tropical forests comprise more than $50 \%$ of the continental biomass, their contribution to atmospheric trace gases budgets is poorly documented. In this respect, one problem relates to the strengths of sources and sinks associated with chemical species. More particularly we should be able to distinguish the exchanges between the atmospheric boundary layer and the top of the canopy from the emissions or absorptions by the litter. Another problem is to model chemical reactions that occur under the canopy i.e. that area screened from solar light. As a first step, an experiment was conducted in the Guyana forest in March 1985, during which $\mathrm{C}_{2}-\mathrm{C}_{6}$ non methane hydrocarbons (NMHC) were measured in the air, together with $\mathrm{CO}_{2}$ and its associated ${ }^{13} \mathrm{C}$ isotopic composition.

Sampling and measurements

Air samples were collected in 6 liter evacuated stainless steel canisters fitted with "NUPRO" bellow valves. For the NMHC, the sample analysis was performed in the laboratory by gas chromatography, using a micro-packed column of n-octane on porasil $c$, and a FID detector, according to a technique previously described [zimmerman, 1977; Mindrup, 1978; Bonsang and Lambert, 1985]. Unfortunately this method did not effectively separate isomers of butene and pentene, and therefore air samples were also analysed on a $\mathrm{Al}_{2} \mathrm{O}_{3} / \mathrm{KCl}$ Porous Layer Open Tubular Capillary Column (Chrompack). As previous work has shown, storage efficiency of $\mathrm{C}_{2}-\mathrm{C}_{6}$ NMHC in stainless steel canisters over a few weeks does not result in significant losses [Bonsang et al., 1986].

Copyright 1987 by the American Geophysical Union.

Paper number 718022 .

$0094-8276 / 87 / 007 \mathrm{~L}-8022 \$ 03.00$
$\mathrm{CO}_{2}$ concentrations where measured in the same samples according to a technique described elsewhere [Komhyr et al.,1985; Bonsang et al., 1986].

Samples were collected, at twilight $16: 30 \mathrm{p}$. m.), in the equatorial forest of French Guyana $\left(5.5^{\circ} \mathrm{N}-53^{\circ} \mathrm{W}\right)$, beneath the canopy at two distinct levels: $2 \mathrm{~cm}$ and $120 \mathrm{~cm}$ above the litter.

The NMHC are listed in Table 1 . We note that acetylene was not detectable $(<0.020 \mathrm{ppbv})$, indicating a lack of anthropogenic influence and local contamination. On the opposite, the high $\mathrm{CO}_{2}$ concentrations of the order of $445 \mathrm{ppm}$ at soil level and $450 \mathrm{ppm}$ at $1 \mathrm{~m}$ height indicate strong natural biological sources. This point is supported by unusual isotopic ${ }^{13} \mathrm{C} /{ }^{12} \mathrm{C}$ compositions of $-11.88 \%$ near the ground and $-10.66 \%$ at $120 \mathrm{~cm}$ ( $P$. Monfray; personal communication).

\section{Interpretation}

For the NMHC, we can distinguish the usual low reactive species (ethane and propane) which do not show any significant vertical concentration gradient, from the other species for which vertical concentration gradients were observed within the first metre above the soil surface. Moreover, these gradients were different for the different species: the concentration differences increased with their carbon number and their degree of insaturation, i.e. their chemical reactivity.

Therefore, it is impossible to account for these experimental results by only a ventilation of the source into the atmosphere. In such a case, the concentration ratios between the two levels should be obviously identical for all the species. In contrast, the interpretation must combine together vertical slow eddy diffusion and chemistry.

Assuming that NMHC are principally removed through a first order chemical reaction, the hypothesis of a continuous soil production followed by a vertical diffusion leads, for short lived species, to a distribution of their mixing ratios versus height :

$$
\partial c_{z} / \partial t=\partial / \partial z\left(k_{z} \cdot \partial c_{z} / \partial z\right)-\lambda c_{z}
$$

where $C_{z}$ is the mixing ratio of a given species at height $z, K_{z}$ is the vertical diffusivity coefficient and $\lambda^{z}$ the first order constant for chemical decay.

In steady state conditions, and assuming $\mathrm{K}_{z}$ constant within the considered altitude range, we have between $z$ and the ground level for every NMHC (except ethane and propane):

$$
c_{z}=c_{0} \exp \left[\left(-\sqrt{\lambda / K_{z}}\right)(z)\right] \quad \text { or: }
$$

$\left(\operatorname{Ln} C_{0}-\operatorname{Ln} C_{z}\right) / z=\sqrt{\lambda / K_{z}}=\sqrt{k_{x} \cdot[x] / K_{z}}$

Where $[\mathrm{X}]$ is the concentration of the chemical 
TABLE 1 : NMHC mixing ratios in the Guyana Forest.

Specie $\quad \mathrm{N}^{\circ} \quad \mathrm{C}_{\mathrm{z}}$ level $1 \quad \mathrm{C}_{\mathrm{z}}$ level 2 Flux from the litter Lifetime (hours) in $10^{-8} \mathrm{~g} \mathrm{C} \mathrm{m}^{-2} \mathrm{~h}^{-1}$

\begin{tabular}{|c|c|c|c|c|c|}
\hline $\mathrm{C}_{2} \mathrm{H}_{2}$ & & $<0.020$ & $<0.020$ & --- & --- \\
\hline & & 1.410 & 1.430 & --- & --- \\
\hline & & 0.260 & 0.280 & -- & --- \\
\hline n $\mathrm{C}_{4} \mathrm{H}_{10}$ & (1) & 0.095 & 0.070 & 4.5 & 14.8 \\
\hline isoc ${ }_{4} \mathrm{H}_{10}$ & & $<0.020$ & $<0.020$ & --- & -- \\
\hline n $\mathrm{C}_{5} \mathrm{H}_{12}$ & (2) & 0.106 & 0.064 & 9.5 & 5.3 \\
\hline isoC $_{5} \mathrm{H}_{12}$ & & 0.053 & $<0.020$ & --- & --- \\
\hline n $\mathrm{C}_{6} \mathrm{H}_{14}$ & & 0.030 & $<0.020$ & -- & --- \\
\hline c. & (3) & 1.595 & 0.780 & 73 & 2.75 \\
\hline $\mathrm{C}_{3} \mathrm{H}_{6}$ & (4) & 0.577 & 0.238 & 46 & 1.70 \\
\hline $1-\mathrm{C}_{4} \mathrm{H}_{8}$ & (5) & 0.048 & 0.020 & 5 & 1.74 \\
\hline iso- $\mathrm{C}_{4} \mathrm{H}_{8}$ & (6) & 0.134 & 0.044 & 16 & 1.10 \\
\hline $1-\mathrm{C}_{5} \mathrm{H}_{10}$ & (7) & 0.392 & 0.086 & 69 & 0.60 \\
\hline & (8) & 0.083 & 0.014 & 19 & 0.42 \\
\hline
\end{tabular}

Mixing ratios of aliphatic NMHC measured in the Guyana forest (in ppbv) at level 1 (soil) and level $2\left(120 \mathrm{~cm}\right.$. height), and corresponding fluxes (in $10^{-8}$ $\mathrm{g}$ of carbon. $\mathrm{m}^{-2} \cdot \mathrm{h}^{-1}$ ) and calculated lifetimes (in hours). Calculations assume $\mathrm{K}_{\mathrm{z}}=3 \mathrm{~cm}^{2} \cdot \mathrm{s}^{-1}$, which corresponds to a $\mathrm{OH}$ concentration of $10^{7}$ radicals $\mathrm{cm}^{-3}$.

species $x$, assumed to be that which reacts with the considered $\mathrm{NMHC}$, and $\mathrm{k}_{\mathrm{x}}$ is the corresponding first order kinetic constant.

To progress it is now necessary to examine what chemical species could be involved in the NMHC destruction.

It is well known that oxidation by $\mathrm{OH}$ radicals is the preponderant sink for NMHC, although alkenes also react, to a lower extent, with ozone. Furthermore, $\mathrm{NO}_{3}$ radicals created through the reaction: $\mathrm{NO}_{2}+\mathrm{O}_{3} \rightarrow \mathrm{NO}_{3}+\mathrm{O}_{2}$ can in some cases play a significant role in alkene oxidation reactions, particularly at night or when their destruction by photochemical processes is inefficient [Atkinson et al., 1984a,b,c; Atkinson and Aschmann, 1984].

Therefore, under a canopy, where there is reduced sunlight, the contribution of $\mathrm{OH}$ oxidation is believed to be decreased, whereas that of ozone and $\mathrm{NO}_{3}$ radicals could be comparatively enhanced. As the kinetic constants $k_{\mathrm{O} 3}$ and $\mathrm{k}_{\mathrm{NO} 3}$ covary with the $k_{\mathrm{OH}}$ rate constant [Atkinson, 1985], the vertical gradients of NMHC observed could be accounted for by oxidation by any of these species.

However, it is possible to show that only oH radicals play a significant role in NMHC oxida$t$ ion. In effect the ratios $[\mathrm{X}] / \mathrm{K}_{\mathrm{z}}$, calculated for $\mathrm{OH}, \mathrm{O}_{3}$, and $\mathrm{NO}_{3}$ from the vertical concentrations gradients, by using equation (1), are plotted in figure 1 versus the kinetic constants $k_{x}$. Clearly, the $[\mathrm{X}] / \mathrm{K}$, values obtained are scattered over an order of magnitude for ozone and over 3 orders of magnitude for $\mathrm{NO}_{3}$ radicals. The only consistent result is obtained with oH radicals for which the ratio $[\mathrm{OH}] / \mathrm{K}_{\mathrm{z}}$ is equal to $3.4 \pm 1.6 \mathrm{x}$ $10^{6}$ molecule. $\mathrm{cm}^{-5} . \mathrm{s}$.

As samples were collected under very low wind conditions, the $\mathrm{K}_{\mathrm{z}}$ value cannot be deduced from micrometeorological parameters. However, using Radon-220 as a tracer of ground emissions, Druil- het [1966] has found that, under the canopy in conditions of high stability, $\mathrm{k}_{z}$ is in the range of 1 to $10 \mathrm{~cm}^{2} \mathrm{~s}^{-1}$. A figure of $3 \mathrm{~cm}^{2} \mathrm{~s}^{-1}$ will be utilized in the following discussion. Such a diffusivity coefficient would lead to a concentration of $1 \times 10^{7}$ oH radicals. $\mathrm{cm}^{-3}$ which will be discussed further. This figure leads to atmospheric lifetimes ( $1 / \lambda$, deduced from equation (1)) lower than half a day for those species for which a vertical gradient was observed (see table 1). As the dynamics of air mass exchanges in the equatorial forest follows a diurnal cycle [Clairac, 19861, a steady state can only be established for species with lifetimes of half a day or less.

The conditions of our experiment correspond to a case where the classical Fick's law of diffusion can be applied. Thus, the production $F$ of an NMHC per unit area is given by:

$$
F=-K_{z}\left(\partial c_{z} / \partial z\right)
$$

The fluxes are therefore proportional to $\mathrm{K}_{z}$. The values given in Table 1 correspond to a figure of $3 \mathrm{~cm}^{2} \mathrm{~s}^{-1}$ for $\mathrm{K}_{\mathrm{z}}$. These data show that alkenes are the major contributor $(94 \%)$ to the $\mathrm{C}_{2}-\mathrm{C}_{5}$ NMHC fluxes in forest with values approaching $2.5 \times 10^{-6} \mathrm{gC} \mathrm{m}^{-2} \cdot \mathrm{h}^{-1}$. This flux is small relative to the figures published for continents and oceans [Ehhalt and Rudolph, 1984; Bonsang and Lambert, 1985; Blake and Rowland, 1986; Bonsang et al., 1986]. Ethylene appears to be the major NMHC released from the litter. The degradation of organic matter by microbial activity, is the likely mechanism responsible for these emissions according to van cleemput et al. [1982], and Sawada and Totsuka [1986]. The "signature" of this source is comparable to that of other natural processes occurring in surface seawater [Lamontagne et al., 1973; Bonsang et al., 1986], but this is probably different from that of trees 


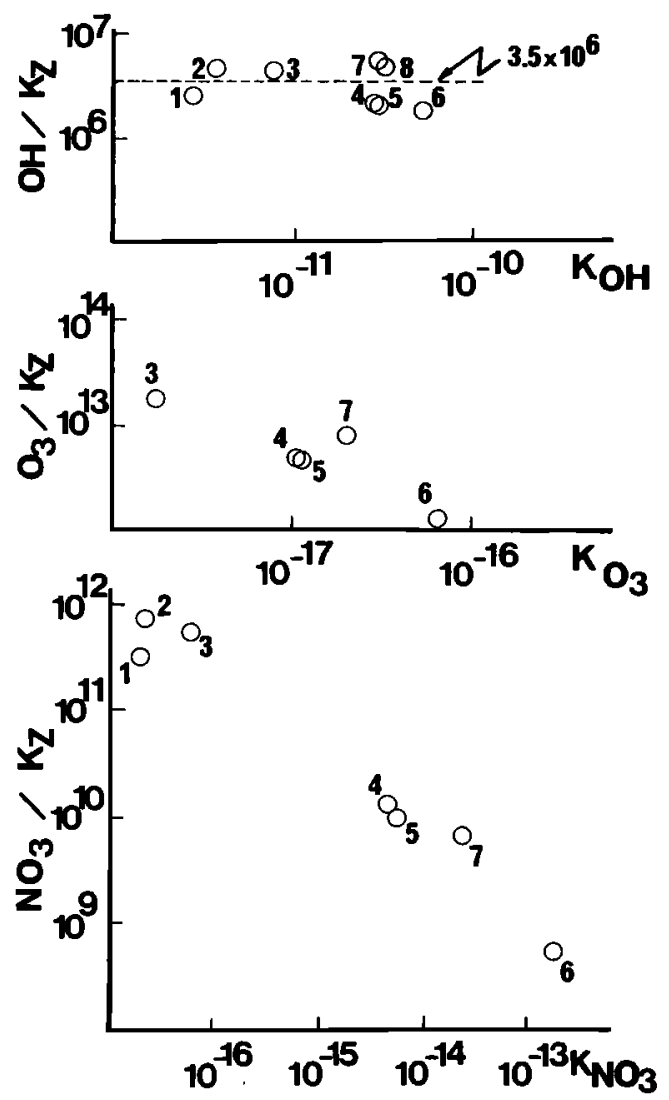

Fig. 1 : Oxidizer concentration to diffusivity ratios calculated for different NMHC in the case of $\mathrm{OH}, \mathrm{O}_{3}$, and $\mathrm{NO}_{3}$.

See caption Table 1 for the name of the species.

$\mathrm{K}_{\mathrm{OH}}$ from Atkinson et al. [1979] and Atkinson and Aschmann [1984]; $K_{03}$ from Herron and Huie [1974], Atkinson et al. $\left[1984^{b}\right]$ and deduced from Atkinson [1985]; $\mathrm{K}_{\mathrm{NO} 3}$ from Atkinson et al. $\left[1984^{\mathrm{a}, b, c}\right]$ and deduced from Atkinson [1985].

emissions characterized by a preponderance of isoprene and terpenes [Greenberg and Zimmerman, 1984; Lamb et al., 1985].

\section{Discussion}

Only one set of samples was obtained and measured in this experiment. However, owing to the consistency of all the above mentioned results on NMHC vertical gradients, $\mathrm{CO}_{2}$ concentrations and isotopic compositions, there is a compelling evidence that the $\mathrm{OH}$ radicals concentration was suprisingly high under the canopy of this equatorial forest. In effect, the figure of $3 \mathrm{~cm}^{2} \mathrm{~s}^{-1}$, here adopted for $\mathrm{K}_{2}$, corresponds to $1 \times 10^{7}$ OH radicals per $\mathrm{cm}^{3}$, which is close to the highest values mentioned for the free troposphere [Hewitt and Harrison, 1985; Crutzen, 1982 ].

Though, this $O H$ concentration is consistent with the existence of vertical gradients within 1 metre. It is important to note that the smallest acceptable value of $\mathrm{K}_{\mathrm{z}}$ is the molecular diffusivity of gases in air i.e. $0.1 \mathrm{~cm}^{2} . \mathrm{s}^{-1}$ and therefore the $\mathrm{OH}$ concentration could by no way be smaller than $3 \times 10^{5}$ or radicals per $\mathrm{cm}^{3}$.

One fundamental problem relates to how oH radicals can be generated in conditions of low photochemistry, where the usual process for $O H$ production through the photolysis of ozone followed by the reaction of oxygen radicals with water vapour is unimportant. An indirect mechanism of $\mathrm{OH}$ production from $\mathrm{NO}$ and $\mathrm{HO}_{2}$ radicals (through the reaction: $\mathrm{NO}+\mathrm{HO}_{2} \rightarrow \mathrm{NO}_{2}+\mathrm{OH}$ ) has been proposed by Hard et al. [1986] to explain the presence of $O H$ radicals at night in urban areas. In the case of the forest, model calculations show that, even at night, the air above the canopy should be very rich in $\mathrm{HO}_{2}$ radicals produced by the oxidation of organic species: isoprene, terpenes, aldehydes, $\mathrm{CH}_{4}$ [Lopez et al., 1987]. A value of $7 \times 10^{7} \mathrm{HO}_{2} \mathrm{rad}^{4} \mathrm{~cm}^{-3}$ deduced from the diurnal variations given by Logan et al. [1981] at $15^{\circ} \mathrm{N}$, and Lopez et al. [1987] can be used here as the lowest acceptable figure. On the other hand it has been shown by Kaplan et al. [1986] and Kirchoff et al. [1986] that equatorial forest soil is an important source of nitric oxide (NO) which accumulates below the canopy during the persistence of the inversion layer. Typical concentrations reported by these authors are of the order of $10 \mathrm{ppbv}(25$ $\times 10^{10}$ molecules. $\mathrm{cm}^{-3}$ ). Providing that there is an intrusion of tropospheric air beneath the canopy, mixing of $\mathrm{NO}$ and $\mathrm{HO}_{2}$ rich air masses could lead to an indirect $O H$ production at twilight according to the above reaction with a kinetic constant of $8 \times 10^{-12} \mathrm{~cm}^{3}$ molec. ${ }^{-1} \mathrm{~s}^{-1}$ [Hard et al., 1986]. Assuming that the major sinks for $O H$ radicals are the oxidation of $\mathrm{CH}_{4}, \mathrm{CO}$, and $\mathrm{C}_{5} \mathrm{H}_{8}$ (isoprene) whose mixing ratios are respectively of 1.7 ppmv (this work), 80 ppbv and $2.5 \mathrm{ppbv}$ [Gregory et al., 1986], a classical calculation with the kinetic constants generally admitted for these consumption processes [Logan et al., 1981; Atkinson, 1985] leads to a figure of $2 \times 10^{7} \mathrm{OH}$ $\mathrm{rad} . \mathrm{cm}^{-3}$ consistent with our observations.

In conclusion, the measurements reported in this study, despite their small number, strongly suggest the existence, in the Guyana tropical forest, of an indirect photochemical process of OH radicals production, which could be important in similar areas.

Acknowledgements. This research was supported by CNRS, CEA, PIREN and Ministère de l'Environnement. The authors are grateful to Dr. P. Blanc from Laboratoire de Botanique Tropicale (University of Paris VI) for samplings in Guyana forest and to P. Monfray (CFR) for $\mathrm{CO}_{2}$ measurements. They also thank the Greek State organisation for Scholarship for financial support of M. Kanakidou. CFR contribution $N^{\circ} 889$.

References

Atkinson, R., Kinetics and mechanisms of the gas phase reactions of the hydroxyl radical with organic compounds under atmospheric conditions, Chem. Rev., 85, 69-201, 1985.

Atkinson, R., and S. M. Aschmann, Rate Constants for the Reaction of $O H$ Radicals with a Series of Alkenes and Dialkenes at $295 \pm 1 \mathrm{~K}$, Int. J. Chem. Kinet., 16, $1175-1185,1984$.

Atkinson, R., S. M. Aschmann, A. M. Winer, and J. N. Pitts, Jr., Rinetics of the gas phase reactions of $\mathrm{NO}_{3}$ radicals with a serie of dialkenes, cycloalkenes and monoterpenes at 
$295 \pm 1^{\circ} \mathrm{K}$, Env, Sci, Technol, 18, 370-375, $1984^{\mathrm{a}}$.

Atkinson, R., K. R. Darnall, A. C. Loyd, A. M. Winer, and $J$. N. Pitts, Jr., Kinetics and mechanisms of the reactions of the hydroxyl radical with organic compounds in the gas phase, Adv. Photochem., 11, 375-488, 1979.

Atkinson, R., C. N. Plum, W. P. L. Carter, A. M. Winer, and J. N. Pitts, Jr., Kinetics of the gas phase reactions of NO3 radicals with a series of alkanes at $296 \pm 1^{\circ} \mathrm{K}$, J. Phys. Chem, 88, 2361-2364, 1984 .

Atkinson, R., C. N. Plum, W. P. L. Carter, A. M. Winer, and J. N. Pitts, Jr., Rate constants for the gas-phase reactions of nitrate radicals with a serie of organics in Air at $298 \pm 1^{\circ} \mathrm{K}$, J. Phys. Chem., 88, 1210-1215, $1984^{\mathrm{C}}$.

Blake, D. R., and F. S. Rowland, Global atmospheric concentrations and source strength of ethane, Nature, 321, 231-233, 1986.

Bonsang, B., and G. Lambert, Non methane hydrocarbons in an oceanic atmosphere, J. Atm. chem., 2, 257-271, 1985.

Bonsang, B., M. Kanakidou, G. Lambert, and P. Monfray, The marine source of $\mathrm{C2}-\mathrm{C} 5$ aliphatic hydrocarbons, J. Atm. Chem. (in press), 1986.

Crutzen, P. J., The global distribution of hydroxyl, in Atmospheric Chemistry, edited by E. D. Goldberg. pp. 313-328, springer-verlag, Berlin, Heidelberg, New York., 1982.

Clairac, B., L'aérosol en foret tropicale humide d'Afrique. Application aux échanges entre la forêt et son environnement, Thèse d'état, 202 pp., Université Paul Sabatier, Toulouse., Sept. 1986.

Druilhet, A., Diffusion de la radioactivité naturelle de l'air dans les basses couches de l'atmosphère, Thèse de doctorat de spécialité, Université Paul Sabatier, Toulouse, 1966.

Ehhalt, D. H. and J. Rudolph, on the importance of light hydrocarbons in multiphase atmospheric systems, Rep. Jij]-2942, 43pp., KFA, Jülich, F.R.G., 1984.

Greenberg, J. P. and P. R. Zimmerman, Nonmethane Hydrocarbons in Remote Tropical, Continental, and Marine Atmospheres, J. Geophys. Res., 89, $4767-4778,1984$.

Gregory, G. L., R. C. Harriss, R. W. Talbot, R. A. Rasmussen, M. Garstang, M. O. Andreae, R. R. Hinton, E. V. Browell, S. M. Beck, D. I. Sebacher, M. A. K. Khalil, R. J. Ferek, and S. V. Harriss, Air chemistry over the tropical forest of Guyana, I. Geophys.Res., 21, 8603 $8612,1986$.

Hard, T. M., C. Y. Chan, A. A. Mehrabzadeh, W. H. Pan, R. J. O'Brien, Diurnal cycle of tropospheric OH, Nature, 322, 617-620, 1986.

Herron, J. T., and R. E. Huie, Rate constants for the reaction of ozone with ethene and propene, from 235 to $620^{\circ} \mathrm{K}$, J. Phys. Chem, 78, 2085 $2088,1974$.

Hewitt, C. N. and R. M. Harrison, Tropospheric concentrations of the hydroxyl radical - A review, Atm. Env, 4, 545-554, 1985.

Kaplan, W. A., Wofsy S. C., Fluxes of nitic oxide and ozone in a central Amazone Terre firme forest, paper presented at AGU spring meeting, Baltimore, (USA), May 19 to $22,1986$.

Kirchoff, W. J. H., Ground based ozone measurements in an equatorial rainforest, paper presented at the AGU spring meeting. Baltimore, (USA), May 19 to 22,1986 .

Komhyr, W. D., R. H. Gammon, T. B. Harris, L. S. Waterman, T. J. Conway, W. R. Taylor and K. H. Thoning, Global atmospheric $\mathrm{CO} 2$ distribution and variations from 1968-1983 NOAA/GMCC CO2 flask sample data, I. Geophys. Res., 20, $5567-5596,1985$.

Lamb, B., H. Westberg, and G. Allwine, Biogenic Hydrocarbon Emissions From Deciduous and Coniferous Trees in the United States, J. Geophys. Bes, $20,2380-2390,1985$.

Lamontagne, R. A., J. W. Swinnerton and W. J. Linnenbom, $\mathrm{Cl}-\mathrm{C} 4$ hydrocarbons in the north and south Pacific, Tellus, 26, 71-77, 1973.

Logan, J. A., J. Prather, S. C. Wofsy, and M. B. Mc Elroy, Tropospheric Chemistry : A global perspective, J. Geophys. Res.e 86, 7210-7254, 1981.

Lopez, A., S. Prieur, J. Fontan, and M. $O$. Barthomeuf, Modelisation de la chimie d'une couche limite atmosphérique non polluee. Influence des hydrocarbures naturels émis par la végétation, Atm. Env. 21, 671-685,1987.

Mindrup, R., The analysis of gases and light hydrocarbons by gas chromatography, I. Chrom. Sci., 16, 380-389, 1978.

Sawada, S., and T. Totsuka, Natural and anthropogenic sources and fate of atmospheric ethylene, Atm. Env, 20, 821-832; 1986.

Van Cleemput, O., A. S. El-Sebaay, and L. Baert, Production of gaseous hydrocarbons in soil in preceedings of the second European Symposium en Physico-Chemical Behaviour of Atmospheric Rollutants edited by $B$. Versino and $H$. Ott, pp. 349-355, D. Reidel, Dordrecht, 1982.

Zimmerman, P. R., Tampa Bay photochemical oxidant study, Rep. EPA 904/9-77-028, U.S. Environ. Prot. Agency, Research Triangle Park, N. C., 1977 .

B. Bonsang, M. Kanakidou and G. Lambert, Centre des Faibles Radioactivités, Laboratoire mixte CNRS-CEA. Avenue de la Terrasse, B.P. $N^{\circ} 1,91190$ Gif-sur-Yvette, FRANCE.

(Received June 30, 1987; accepted October 8, 1987.) 